\title{
Rotary peeling yield of Schizolobium amazonicum (Leguminosae - Caesalpinioideae)
}

\author{
Rafael Rodolfo de MELO ${ }^{1 *}$, Cláudio Henrique Soares DEL MENEZZI², Bruno Ettore PAVAN², \\ Francisco RODOLFO JÚNIOR ${ }^{4}$ \\ 1 Universidade Federal de Mato Grosso (UFMT), Instituto de Ciências Agrárias e Ambientais (ICAA), Avenida Alexandre Ferronato, 1200, Distrito Industrial, 78557-267, Sinop, MT, Brazil. \\ 2 Universidade de Brasília (UnB), Departamento de Engenharia Florestal (EFL), Cx. Pt. 04357, 70904-970, Brasília, DF, Brazil. \\ ${ }^{3}$ Universidade Estadual Paulista (UNESP), Faculdade de Engenharia de Ilha Solteira (FEIS), Rua Monção, 226, 15385-000, Illha Solteira, SP, Brazil. \\ ${ }^{4}$ Universidade Federal do Piauí (UFPI), Departamento de Engenharias (DEng), BR 165, km 03, 64900-000, Bom Jesus, PI, Brazil. \\ * Autor correspondente: rrmelo2@yahoo.com.br
}

\section{ABSTRACT}

The tropical tree Schizolobium amazonicum is native from the Amazonian forest, naturally occurring in Brazil, Peru and Colombia. This work aimed to study the veneer yield made from this species. For this purpose, 50 logs from $S$. amazonicum were rotary peeled in a plywood industry installed in Brazilian Amazon region. The results indicated that $S$. amazonicum had a peeling yield similar or even higher than those usually obtained for species traditionally used for this purpose in Brazil, like those of Pinus and Eucalyptus. It was also observed that the dendrometric parameters of the log can be used to estimate the peeling yield in this species.

KEYWORDS: forest industry, wood veneer, plantation tree.

\section{Rendimento em laminação da madeira de paricá (Schizolobium amazonicum, Leguminosae - Caesalpinioideae)}

\section{RESUMO}

O paricá (Schizolobium amazonicum) é uma espécie nativa da floresta amazônica, que ocorre naturalmente no Brasil, Peru e Colômbia. O objetivo do presente trabalho foi avaliar o rendimento em laminação da madeira de paricá. Para isso foram avaliadas toras da espécie em uma fábrica de compensado instalada na regiáo Amazônica brasileira. Os resultados indicaram que o paricá apresenta um elevado rendimento em laminaçáo, sendo similar ou em alguns casos até superior a espécies tradicionalmente utilizadas para esta finalidade no Brasil, como as dos gêneros Pinus e Eucalyptus. Observou-se ainda que o rendimento em laminação da espécie pode ser estimado por meio dos parâmetros dendrométricos das toras.

PALAVRAS-CHAVE: indústria florestal, laminas, plantios florestais. 


\section{INTRODUCTION}

Schizolobium amazonicum is a fast-growing Brazilian tropical wood species with high productivity $\left(20\right.$ to $30 \mathrm{~m}^{3}$ $\mathrm{ha}^{-1}$ year $\left.^{-1}\right)$. Since 2000 plantations have been established, and currently they cover approximately 85,000 ha. The species has a straight trunk almost without any branch and it produces a white-yellowish low density hardwood: usually less than $0.40 \mathrm{~g} \mathrm{~cm}^{-3}$. It is mainly used to produce wood veneers and plywood. Such characteristics have contributed for the largescale cultivation of this species in homogeneous plantations in Northern Brazil. At the end of its cycle, after four to seven years, $S$. amazonicum produces stem with diameters of 10 to $40 \mathrm{~cm}$ (Melo 2012).

The following species characteristics are highly desirable at industrial point of view: its easy debarking, fast drying, lack of knots and the possibility to be rotary peeled to produce veneer without pretreatments and log rounding. However, plantations has relatively thin stem when harvested (4-6 years) and the traditional lathe used for larger logs is not suitable for the peeling process. According to Melo et al. (2013) to overcome this limitation a new equipment was developed, then enabling the use of thinner logs and providing significant gain in recovery. Instead of log mounting spindles, the new equipment presents tension screws which press and rotate the wood over the blade, enabling the peeling of until $4-\mathrm{cm}$ diameter wood (peeling core), while a traditional lathe could laminate wood up to $12 \mathrm{~cm}$.

According to Huang et al. (2012), the recovery of the peeling process is influenced by several factors, and they highlighted that the quality of the raw material is the most important. Characteristics such as stem conicity and straightness, log diameter and absence of knots and top cracks are considered very important factors to obtain higher recoveries and to produce high-quality veneers.

Nonetheless, such characteristics are not enough for achieving high recoveries since the operational conditions and the type of equipment used are also considered factors that limit productivity improvement (Melo et al. 2013). In the manufacturing of panels, the peeling process is considered that with the highest losses (Hapla et al. 2002). Therefore, by knowing the source of these losses during peeling it is possible to increase the productivity and decrease production costs. Additionally, these improvements provide a better use of the raw material and the manufacture of products with better quality. The technical feasibility of certain wood species for peeling can be evaluated by measuring the yield and comparing it with those obtained for other wood species traditionally used for peeling at industrial level (Bonduelle et al. 2006). In Brazil, two genera of plantations tree species are important: Eucalyptus and Pinus. In this context, this study aimed to evaluate the potential of Schizolobium amazonicum to produce veneer, measuring the peeling yield and predicting the yield from the dendrometric variables of the log.

\section{MATERIALS AND METHODS}

Fifty 5-7-year-old Schizolobium amazonicum Huber ex. Ducke (Leguminosae-Caesalpinioideae) trees were harvested and 170-cm length logs were produced and randomly selected in the yard of a plywood facility located in Northern Brazil. Before the peeling, the logs were numbered and top and bottom circumferences were measured. Further five logs were used to determine wood basic density.

The selected logs were peeled within 72 hours after harvesting, and therefore they were still in wet condition. No heating pretreatment was conducted, whereas debarking was the only processing operation performed before log peeling. This process was performed in a rotary lathe with rollers and without spindles. In this equipment, differently from conventional lathes, the log is not rotated by lateral spindles but by two rollers which press the log against the blade. This machine, which was firstly projected in order to fulfill the $S$. amazonicum peeling demand, can be used to laminate logs with maximum diameter of $40 \mathrm{~cm}$ and to use the peeling core discarded by traditional lathes.

The lathe was adjusted to obtain 1.50 -mm thick veneers. The veneers produced were clipped in different sizes according to their visual quality, whereas the best ones presented $230 \mathrm{~cm}$ x $170 \mathrm{~cm}$ (length x width) and the others, $60 \mathrm{~cm}$ x $170 \mathrm{~cm}$. In the facility where the study was conducted, the differentiation in the dimensions of the veneers is performed aiming at using the veneers with the greatest dimensions and best appearances in plywood surface layers, while the others are used in the core.

The method used for this differentiation was the visual grading which, according to Lara Palma et al. (2012), is performed by industry based on type, quantity and dimensions of the defects found in the veneers. It has been established by industrial practice because there is no specific standard for this wood species. Thus, this aspect was also used to qualify the veneers produced. Thereby, after the peeling of each log the number of surface and core veneers obtained was accounted. Surface veneers were selected through the pre-established parameters: lack of defects (especially knots, checks and faults), uniform color and lack of pith region, apart from veneer size.

The peeling yield was estimated for each of the 50 peeled logs considering the volume obtained through the measurement of length, width and thickness of the veneers produced by each log. For yield calculation, the losses from the process of debarking, rounding and discarded veneers were computed.

The dendrometric variables of the logs used in the process of peeling were assessed through descriptive statistics. The 
volumes obtained in the peeling process were converted into percentage values considering as maximum volume that registered for logs with bark. In order to estimate the peeling recovery, number of veneers produced per log, and yield of both surface and core veneers, the dendrometric characteristics registered for the logs - minimum, maximum and average inside and outside bark diameter; form factor from inside and outside bark diameter; log volume computed from inside and outside bark diameter and bark thickness were used as independent variables.

\section{RESULTS}

The logs used in this study showed average outside bark diameter between $13 \mathrm{~cm}$ and $25 \mathrm{~cm}$, which well represent the diametric amplitude of the S. amazonicum wood used by plywood industries (Table 1). With respect to the bark, an average value lower than $0.5 \mathrm{~cm}$ was observed, which indicates a species with relatively thin bark. Despite being usually disregarded, the bark proportion of a tree is also one of the essential parameters to determine veneer recovery.

In total, 485 veneers were obtained from the 50 peeled $\operatorname{logs}-123$ surface veneers and 362 core veneers. The difference between the average thickness found $(1.55 \pm 0.14 \mathrm{~mm})$ and the pre-established nominal thickness $(1.50 \mathrm{~mm})$ was low (less than $4 \%$ ), which indicates an effective adjustment in the lathe's regulation (Table 2). In this case, the thickness found was slightly higher than the nominal. Bortoletto Jr. (2008) emphasizes that it is better to produce thicker veneers, because during drying the thickness of veneer is reduced and further thickness reduction is observed when the plywood is hot-pressed.

The peeling of $S$. amazonicum veneers provided a $59.9 \%$ yield and, as a result, a $40.1 \%$ loss (Table 3). About 54\% of veneers had potential for use as surface veneers, while the rest, 46.3\%, as core. On the other hand, Melo (2012) suggested that only one third of the useful volume of the veneers produced with this species would be suitable for use as surface in panels. Table 4 presents the comparison of peeling recoveries in different studies. It is clear the peeling
Table 1. Volume (V), diameter with bark (Db), bark thickness (Tb), basic density $(\rho)$ and form factor (Ff) of Schizolobium amazonicum logs.

\begin{tabular}{lccccc}
\hline \multirow{2}{*}{ Values } & $\mathrm{V}$ & $\mathrm{Db}$ & $\mathrm{Tb}$ & $\rho$ & $\mathrm{Ff}$ \\
\cline { 2 - 6 } & $\left(\mathrm{x} 100 \mathrm{~m}^{3}\right)$ & $\ldots \ldots(\mathrm{cm})$ & $\ldots .$. & $\left(\mathrm{g} \mathrm{cm}^{-3}\right)$ & $\ldots$ \\
\hline Maximum & 8.34 & 25.0 & 0.72 & 0.42 & 0.98 \\
Mean & 4.23 & 17.7 & 0.44 & 0.34 & 0.93 \\
Minimum & 2.33 & 13.2 & 0.32 & 0.27 & 0.88 \\
CV $(\%)^{*}$ & 14.6 & 12.9 & 27.3 & 11.8 & 3.23 \\
\hline Total $^{*}$ & 50 & 50 & 50 & 30 & 50 \\
\hline
\end{tabular}

*number of samples used to obtain mean values.

Table 2. Number and volume of surface veneers (Ns; Vs) and core veneers (Nc; Vc) obtained from the logs and observed thickness veneers (To) of Schizolobium amazonicum veneers.

\begin{tabular}{lccccc}
\hline \multirow{2}{*}{ Values } & Ns & Nc & Vs & Vc & To \\
\cline { 2 - 6 } & $\ldots$ & $\ldots$ & $\left(\times 100 \mathrm{~m}^{3}\right)$ & $\left(\mathrm{x} 100 \mathrm{~m}^{3}\right)$ & $(\mathrm{mm})$ \\
\hline Maximum & 7.00 & 17.0 & 4.21 & 2.67 & 1.79 \\
Mean & 2.46 & 7.24 & 1.48 & 1.14 & 1.55 \\
Minimum & 0.00 & 0.00 & 0.00 & 0.00 & 1.33 \\
CV(\%) & 78.9 & 45.9 & 79.0 & 45.6 & 9.09 \\
Total $^{*}$ & 123 & 362 & 123 & 362 & 150 \\
\hline
\end{tabular}

*number of samples used to obtain mean values.

Table 3. Percentage of losses observed for Schizolobium amazonicum log peeling.

\begin{tabular}{ll}
\hline Parameter & Percentage \\
\hline Surface veneer & 32.3 \\
Core veneer & 27.6 \\
Discarded veneer & 16.5 \\
Peeling core & 12.0 \\
Rounding & 6.70 \\
Bark & 4.90 \\
\hline
\end{tabular}

yield found here was similar or even higher than those found for Eucalyptus and Pinus species.

The model adjusted to estimate the peeling recovery aggregated two variables: minimum inside bark diameter and outside-bark form factor (Figure 1). It was verified an adjusted coefficient of variation value of 0.48 and a standard error of the estimate of 9.96. Using the minimum inside bark

Table 4. Comparative yield of Schizolobium amazonicum peeling with others sources.

\begin{tabular}{|c|c|c|c|c|c|c|}
\hline \multirow{2}{*}{ Source } & \multirow{2}{*}{ Species } & debarking & rounding & handling & peeling core & yield \\
\hline & & \multicolumn{5}{|c|}{ 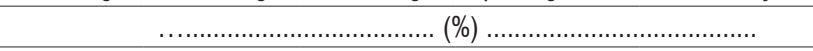 } \\
\hline Bortoletto Jr. (2008) & P. merkussi & 13.5 & 15.1 & 5.3 & 8.2 & 57.9 \\
\hline Bonduelle et al. (2006) & Pinus spp. & - & 35.0 & 4.0 & 13.0 & 49.3 \\
\hline Almeida et al. (2004) & E. urograndis & 12.6 & 19.7 & - & 10.9 & 56.8 \\
\hline Bortoletto Jr. \& Belini (2002) & S. parahyba & 8.4 & 22.9 & 6.2 & 9.9 & 52.6 \\
\hline Hoffmann (2009) & S. amazonicum & - & - & 15.27 & 6.4 & 55.7 \\
\hline This study & S. amazonicum & 4.9 & 6.7 & 16.52 & 12.0 & 59.9 \\
\hline
\end{tabular}


diameter data it was possible to estimate the number of veneers produced by each $\log$ with an $\mathrm{R}^{2}$ aj value of 0.56 (Figure 2).

\section{DISCUSSION}

The peeled logs presented diameter at breast height ranging from 13 to $25 \mathrm{~cm}$, which is within the range usually found for S. amazonicum logs used for industrial purposes. Hoffmann (2009), while performing the dendrometric characterization of $S$. amazonicum commercial plantations with ages from five to seven years, observed diameters ranging from 11 to $29 \mathrm{~cm}$ for the 180 trees surveyed, only $12(6.67 \%)$ were outside the interval registered in the present study. The bark thickness was about $0.5 \mathrm{~cm}$, which means a species with thin bark. Sometimes this characteristic is not properly considered in peeling yield studies, but it is a very important factor. For instance, Bortoletto Jr. and Belini (2002) observed for $S$. parahyba - a similar species to $S$. amazonicum - an improvement in peeling recovery over $8 \%$ when logs peeled with and without bark were compared. For $S$. parahyba, the average bark thickness registered was $0.80 \mathrm{~cm}$.

Regarding the basic density, the average value registered $\left(0.34 \mathrm{~g} \mathrm{~cm}^{-3}\right)$. Table 1 also shows that the average form factor of the veneers was 0.93 , which is similar to those found for logs from species traditionally peeled in lathes, such as those from Pinus (Bonduelle et al. 2006) and Eucalyptus genera (Almeida et al. 2004). The low basic density observed in addition to its straight stem qualifies $S$. amazonicum as a species with technological characteristics suitable for peeling.

The yield registered in this study is similar to those previously observed in either the same species (Hoffmann 2009) or different species (Bortoletto Jr. 2008; Almeida et

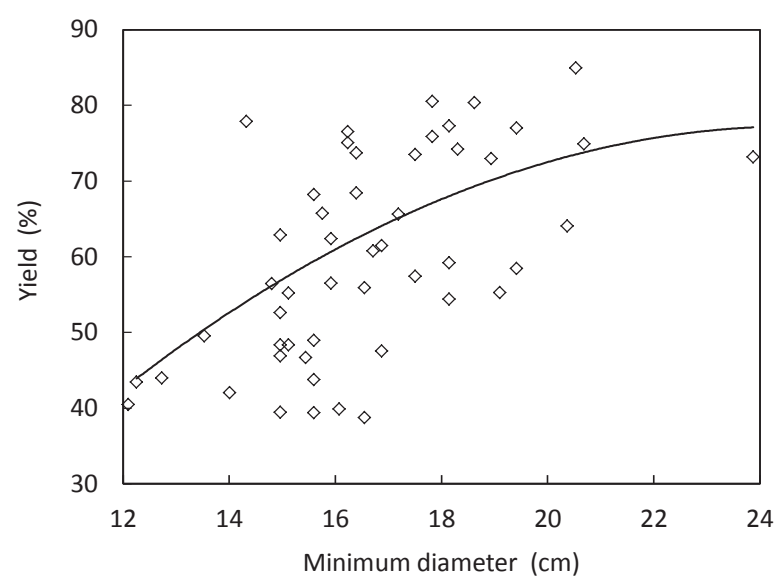

Figure 1. Adjusted equation for yield $(Y)$ according to the debarked log volume (V), form factor with bark (F) and debarked log minimum diameter (D) of Schizolobium amazonicum logs. Adjusted model $Y=134.2+1503 \mathrm{~V}$ $+102.9(1 / F)+0.005 D^{3} ; F=14.51 ;$ Prob $>F=<.0001 ; R^{2}{ }_{a j}=0.48$; Syx $=9.96$. al. 2004). Therefore, this indicates that S. amazonicum has important potential for the production of panels. It means the $S$. amazonicum can become a competitive species since it presents high productivity and yields high quality veneers, as mentioned by Hoffmann (2009).

Besides its elevated yield, S. amazonicum does not need pretreatments for peeling, which is needed for most species (Mayer et al. 2007), reducing costs and processing time. The low average basic density $\left(0.34 \mathrm{~g} \mathrm{~cm}^{-3}\right)$ found in this study enables log peeling without heating. Furthermore, it should be highlighted the absence of knots in the veneers owing to this species' high capacity of natural pruning. For other species without this characteristic, likewise those of the genus Pinus, the artificial pruning is necessary to obtain quality veneers. This procedure presents technical and economical implications in the peeling process, encumbering the final product.

The main losses in the process of peeling were because of the discard of veneers (16.5\%). The elevated value of discarded veneers in the present study is possibly related to the low thickness of the veneers produced $(1.50 \mathrm{~mm})$. Nevertheless, Hoffman (2009) also found high values assessing the same species. According to Bortoletto Jr. (2008), although thinner veneers provide higher peeling yield, the number of discarded veneers can be considerably higher, because the veneer fragility which leads to be easily broken during handling process. The second greatest loss was observed in peeling core $(11.9 \%)$, which was higher than those registered by Bortoletto Jr. and Belini (2002) for S. parahyba.

Although these works had been performed using conventional lathes with spindles which provide a higher core cylinder, such type of lathe also differs from that used

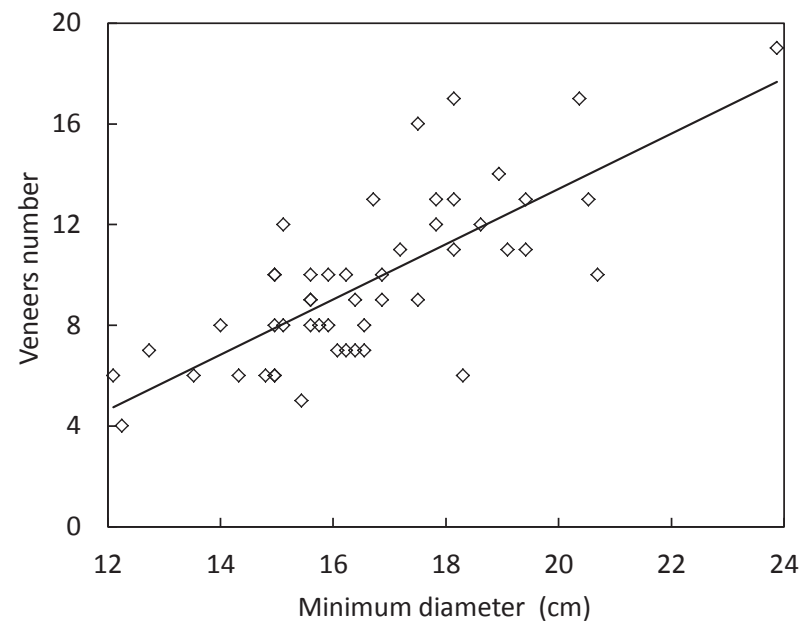

Figure 2. Adjusted equation for veneers produced for logs $(N)$ according to the debarked log minimum diameter $(D)$ of Schizolobium amazonicum logs. Adjusted model $N=-8.55+1.10 D ; \mathrm{F}=61.34 ;$ Prob $>\mathrm{F}=<.0001 ; \mathrm{R}^{2}$ a. $=0.56 ;$ Syx $=2.22$. 
for $S$. amazonicum as it enables the peeling of logs with greater diameters. Bonduelle et al. (2006) emphasize that the percentages of remainders with peeling core can be minimized by logs with higher diameters, which might explain the difference observed. Another reason may be related to the thickness of the produced veneers, since according to Bortoletto Jr. (2008) thinner veneers may generate higher recoveries.

The losses in recovery were also due to log rounding (6.68\%) and debarking (4.90\%). It is important to emphasize that $\log$ conicity and bark thickness, which were responsible for losses in rounding and debarking, are inherent parameters of each species. Such characteristics can be minimized through genetic improvement and progeny selection (Ohashi et al. 2010).

Our results agree with those reported by Almeida $\mathrm{et} \mathrm{al}$. (2004), Bonduelle et al. (2006) and Huang et al. (2012). These authors found that the greater the log diameter and better the form factor the higher the peeling yield. However, there is a limit for the improvement of these characteristics: for instance, from a certain diameter both the recovery and the quality of the veneers do not change or even tend to decreasing. The form factor can significantly affect the quality of the veneers, especially the veneers' grain direction and roughness.

\section{CONCLUSIONS}

Schizolobium amazonicum logs from plantations trees, between ages of five and seven years, presented high potential for the production of veneers. The dendrometric variables of the log could be efficiently utilized in order to estimate the peeling recovery of this species.

\section{ACKNOWLEDGMENTS}

To Coordenação Nacional de Aperfeiçoamento de Pessoal de Nível Superior (CAPES) for the Doctor's degree scholarship in Forest Science granted to the first author. To Centro de Pesquisa do Paricá (CPP), Portas Itinga Ltda and Rio Concrem Idustrial Ltda. Industries, for supplying veneer and granting permission for conducting the research.

\section{REFERENCES}

Almeida, R.R.; Bortoletto Jr., G.; Jankowsky, I.P. 2004. Produção de lâminas a partir de clones do híbrido Eucalyptus grandis $x$ Eucalyptus urophylla. Scientia Forestalis, 32: 49-58.

Bonduelle, G.M.; Iwakiri, S.; Chies, D.; Martins, D. 2006. Fatores que influenciam no rendimento em laminaçáo de Pinus spp. Floresta e Ambiente, 12: 35-41.

Bortoletto Jr., G. 2008. Avaliação da qualidade da madeira de Pinus merkusii para produção de lâminas. Scientia Forestalis, 36: 95-103.

Bortoletto Jr., G.; Belini, U.L. 2002. Produção de lâminas e manufatura de compensados a partir da madeira de guapuruvu (Schizolobium parahyba Blake.) proveniente de um plantio misto de espécies nativas. Cerne, 8:16-28.

Hapla, F.; Meggers, H.; Militz, H.; Mai, C. 2002. Investigation on the yield and quality of sliced veneer produced from beech trees (Fagus sylvatica L.) containing red heartwood. Holz als Roh-und Werkstoff, 60: 440-442.

Hoffmann, R.G. 2009. Caracterização dendrométrica e avaliação do rendimento em laminação de madeira em plantios de paricá (Schizolobium amazonicum Huber ex. Ducke) na regiáo de Paragominas, PA. Dissertação de Mestrado, Universidade Federal do Espírito Santo Federal, Alegre. 97p.

Huang, S.H.; Wang, B.J.; Li, J.; Lei, Y.; Dai, C.; Sun, X. 2012. Characterizing changbai larch through veneering. Part 2: effect of diameter at breast height and radial growth. Bioresouces, 7: 3076-3092.

Lara Palma, H.A.; Escobar, J.F.; Ballarin, A.W.; Leonello, E.C. 2012. Influência da qualidade das lâminas no desempenho mecânico à flexão de painéis compensados de Hevea brasiliensis. Floresta e Ambiente, 19: 133-140.

Mayer, I.; Koch, G.; Puls, J. 2007. Chemical investigations on boiling process waters in face veneer production. Holz als Roh-und Werkstoff, 65: 315-320

Melo, R.R. 2012. Avaliação de variáveis tecnológicas na produção de painéis LVL confeccionados com paricá (Schizolobium amazonicum Huber ex Ducke). Tese de Doutorado, Universidade de Brasília, Brasília. 166p.

Melo, R.R.; Del Menezzi, C.H.S.; Souza, M.R.; Stangerlin, D.M. 2013. Avaliação das Propriedades Físicas, Químicas, Mecânicas e de Superfície de Lâminas de Paricá (Schizolobium amazonicum Huber ex. Ducke). Floresta e Ambiente, 20: 238-249.

Ohashi, S.T.; Yared, A.G.; Farias Neto, J.T. 2010. Variabilidade entre procedências de paricá Schizolobium parahyba var amazonicum (Huber ex Ducke) Barneby plantadas no município de Colares - Pará. Acta Amazonica, 40: 81-88.

Recebido em 14/06/2013

Aceito em 12/11/2013 
